\title{
The Impact of Emotional Intelligence Level on The Depression Vulnerability
}

\author{
Relacje między poziomem inteligencji emocjonalnej a podatnością na depresję - przegląd zagadnień \\ Marta Cudzik ABDEF, Ewelina Soroka DEF https://orcid.org/0000-0001-6909-2749, \\ Marcin Olajossy DE https://orcid.org/0000-0002-1001-3185
}

II Department of Psychiatry and Psychiatric Rehabilitation, Medical University of Lublin

\begin{abstract}
Introduction: Recently the issue of emotional intelligence has become a widespread theme of discussion. This review paper is made a contribution to this debate. Discovering of effective predictive and protective factors for depression would have farreaching consequences for society, science and economy.

Material and Methods:

To investigate this issue, we searched articles available in the Google Scholar and PudMed databases under the following terms: emotional intelligence, depression, emotional intelligence and depression for the years 1999-2019. Accessible literature allowed to show basic information of emotional intelligence, detect a system of relationships between emotional intelligence level and depression, and present recommendations.

Results and Discussion: The result of this analysis is a statement that all components of emotional intelligence can be a defense against depression. People with high abilities in regulation their own emotions have large social support, what protect them against depression. The capable managing one's own and others' emotions create large and deep interpersonal relationships, what provide more emotional support and tangible assistance during everyday challenges. Stressful life events are among the most powerful predictors of depression, and high level of emotional intelligence enable to cope with them more effectively.

Conclusions: The present text will constitute an impulse to explore this theme more. Moreover, there is a recommendation for researchers to create more effective and simplified tests for examining the level of emotional intelligence in case of spreading them much more and use them in a routine psychiatric practice. A confirmation of the title hypothesis can stand a key to struggle with depression.
\end{abstract}

Keywords: emotional intelligence, depression, emotions, feelings

\section{Streszczenie}

Wstęp: Zagadnienie inteligencji emocjonalnej stało się w ostatnim czasie bardzo rozpowszechnionym tematem dyskusji. Niniejsza praca ma stanowić przyczynek w owej debacie. Odnalezienie skutecznego czynnika predykcyjnego i protekcyjnego dla depresji miałoby daleko idące konsekwencje dla społeczeństwa, nauki oraz gospodarki i ekonomii.

Materiał i metoda: Do zbadania tej tematyki wykorzystano dostępne artykuły z bazy Google Scholar oraz PubMed pod hasłami: inteligencja emocjonalna, depresja, inteligencja emocjonalna a depresja w przedziale czasowym od 1999 do 2019 roku. Zdobyte piśmiennictwo pozwoliło na przybliżenie podstawowych informacji dotyczących inteligencji emocjonalnej, zauważenie i stworzenie schematu systemu zależności występujących pomiędzy poziomem inteligencji emocjonalnej a depresją oraz przedstawienie dalszych zaleceń.

Wyniki i dyskusja: Efektem tej pracy jest wniosek, iż wszystkie komponenty inteligencji emocjonalnej mogą stanowić ochronę przed depresją. Osoby z wysokimi umiejętnościami regulowania swoich emocji, posiadają duże wsparcie społeczne, a to zapobiega depresji. Sprawne zarządzanie emocjami swoimi jak i innych osób powoduje, że jednostka potrafi wytworzyć wiele głębokich relacji międzyludzkich, co zapewnia większe wsparcie emocjonalne i namacalną pomoc podczas wyzwań dnia codziennego. Stresujące wydarzenia życiowe są jednym z najsilniejszych predyktorów depresji, a właśnie wysoki poziom inteligencji emocjonalnej pozwala sprawniej sobie z nimi radzić.

Konkluzje: Niniejszy tekst ma stanowić impuls do dalszych badań na tym polu. Ponadto, rekomenduje się badaczom 
stworzenie bardziej efektywnych i uproszczonych testów badających poziom inteligencji emocjonalnej, co ułatwi ich szerokie rozpowszechnienie i stosowanie w rutynowej praktyce psychiatrycznej. Potwierdzenie hipotezy postawionej w tytule może stać się kluczem do walki z depresją.

Słowa kluczowe: inteligencja emocjonalna, depresja, emocje, uczucia

\section{Introduction}

Depression is one of the most common mental illnesses, with which most people have contact in their lives, either directly or indirectly, through their friends and family members. Moreover, depression often leads to suicide thoughts and attempts. Hence, it is necessary to explore this theme and find strategies for early detection and prophylaxis of depression. In this order, over the past decades, scholars have conducted researches focused on the possible utility of emotional intelligence as a potential predictive factor of depression.

\section{Objective}

This paper constitutes a review of the available literature on the impact of emotional intelligence level on the depression vulnerability. Furthermore, this text is intended to draw attention of the scientific community to this kind of usage for this construct and probably to contribute to further researches in this area.

\section{Material and Methods}

To conduct an analysis we used available articles from the PubMed and Google Scholar databases under following notions: emotional intelligence, depression, emotional intelligence and depression for the years 19992019.

In order to present the nature of that phenomenon as best as possible, the article was divided into the following sub-chapters:

1. Emotional Intelligence - definition and its components.

2. The relationships between emotional intelligence and depression;

3. Results and discussion - the level of emotional intelligence like the protective and predictive factor of depression;

4. Conclusions and recommendations.

\section{Emotional Intelligence - definition and its components.}

Emotional Intelligence, EI, is defined as an ability of perceiving, understanding, managing and differentiating one's own and others' emotions [1]. It enables to recognise emotional states and direct them, in this way to regulate and shape own and others' behaviour in exact situation, to achieve targets, cope with everyday situations and force positive affect [2]. Thanks to EI people easier overcome stressful situations, solve conflicts and have more positive life attitude [3]. In one word, emotional intelligence enables healthy mental functioning and, throughout this maintain, mental well-being [4].

Many researchers claim that this construct positively correlates with psychosocial factors, such as: wellbeing, happiness, optimism, life satisfaction, self-esteem, prosocial behaviours, increased quality and quantity of social relationships and marital happiness. Moreover, emotional intelligence protects against depressive symptoms, loneliness, antisocial behaviours, social anxiety, suicidal tendency, alcohol and substance abuse [3].

Mayer and Salovey merged emotions and intelligence as cognitive abilities under one notion of emotional intelligence [5]. Bar-On has created meticulous and clear model of emotional intelligence and because of it, this analysis will be based on this classification. According to Bar-On, emotional intelligence is consisted of 5 general components, in which there are 15 subcomponents: emotional self-awareness, assertiveness, self-regard, self-actualization, independence, empathy, social responsibility, interpersonal relationship, reality testing, flexibility, problem solving, stress tolerance, impulse control, optimism and happiness [2, 3, 6]. More details in tab. 1.

\section{The relationships between emotional intelligence and depression.}

Despite the lack of acquaintance of exact reason of depression, it is suspected that psychological, sociological and physiological factors play a significant role in its etiology of [3]. There are a lot of hypotheses connecting depression with an inability to control negative emotions [4] or poor psychological adjustment [5]. The appropriate level of emotional intelligence can suppress it. Emotional abilities allow to cope with and overcome depression, hopelessness and suicidal ideas. They protect individual against stress and enable to easier adopt to different circumstances [11].

Studies conducted until now show clear relation between the level of emotional intelligence and depression morbidity [2-5, 7-10]. Individuals, who score higher results in emotional intelligence tests, also report lower intensity of depression [10]. These findings suggest a potential impact of EI on clinical depression $[4,5]$.

Emotional intelligence, like a part of an overall 
Table 1. The Bar-On's Emotional Intelligence Model [2, 3, 6]

\begin{tabular}{|c|c|c|}
\hline General component & Subcomponents' names & Characteristics \\
\hline \multirow{5}{*}{$\begin{array}{l}\text { Intrapersonal Emotional } \\
\quad \text { Intelligence }\end{array}$} & Emotional self-awareness & Understanding and managing one's desires and emotions \\
\hline & Assertiveness & $\begin{array}{l}\text { Asserting one's emotions, believes, thoughts and defending } \\
\text { one's rules }\end{array}$ \\
\hline & Self-regard & Understanding oneself, accepting and respecting the self \\
\hline & Self-actualization & Knowing potentials, weaknesses and accepting them \\
\hline & Independence & Leading one's actions, thoughts and values them \\
\hline \multirow{3}{*}{$\begin{array}{l}\text { Interpersonal Emotional } \\
\quad \text { Intelligence }\end{array}$} & Empathy & Understanding others' feelings and respecting them \\
\hline & Social responsibility & $\begin{array}{l}\text { Expressing oneself in active and constructive ways in the } \\
\text { group }\end{array}$ \\
\hline & Interpersonal relationship & $\begin{array}{l}\text { Having and sustaining satisfactory relationships through } \\
\text { lavishing and accepting others' kindness }\end{array}$ \\
\hline \multirow{3}{*}{ Adaptability } & Reality testing & Differentiating subjective and objective impressions \\
\hline & Flexibility & $\begin{array}{l}\text { Adjusting emotions, thoughts and actions to changing } \\
\text { circumstances }\end{array}$ \\
\hline & Problem solving & $\begin{array}{l}\text { Identifying and defining a problem and generating effective } \\
\text { solution }\end{array}$ \\
\hline \multirow{2}{*}{ Stress Management } & Stress tolerance & $\begin{array}{l}\text { Effective withstanding adversity and stress by active coping } \\
\text { with stress }\end{array}$ \\
\hline & Impulse control & Controlling sudden, strong emotions \\
\hline \multirow{2}{*}{ General Mood } & Optimism & Maintaining a positive attitude even under adversity \\
\hline & Happiness & Positive attitude to own and others' life \\
\hline
\end{tabular}

human intelligence, is an ability to think rationally, to deal with society and variable environment. It enables to develop very good interpersonal relationships and have better social support, what is crucial for preventing depression [10].

The extent in which human can lead his own emotions is rooted in his emotional development, emotional experiences, parental attitudes, their treatment and stimulation of child to develop emotionally from early childhood to adulthood. Emotional atmosphere and background are important factors appealing to the level of emotional intelligence $[9,11,12]$.

The size, diversity and frequency of contacts and level of intimacy in social networks is very important. Large and diverse social networks allow to have multiple choice of people, to whom they can turn with problems and elicit adequate help. Besides, the individual can fulfill multiple social roles and feel to be more significant part of his environment, what increases his self-esteem and sense of life. Moreover, contact with multiple groups and people may expose a person to a variety of coping mechanisms, which take an acquaintance of larger amount of mechanisms to solve problems.
Stressful life events are among the most powerful predictors of depression. The high level of emotional intelligence and therefore efficient problem-solving, because of internal and external resources, allow to solve problems fast and effectively and consequently indicate protective role against depression [7].

\section{Results and discussion - the level of emotional intelligence like the protective and predictive factor of depression.}

In the light of presented evidences, there is a conclusion that the high level of emotional intelligence acts like a protective factor of depression $[4,7,9]$. On the other hand, the low level of EI can become a predictive factor of depression $[4,10]$. The components of emotional intelligence defend people against psychological pressures [3].

Achenbach claims that the tumble of emotional intelligence level is a global phenomenon. Moreover, the higher intelligence quotient (IQ), the lower EI. For instance, progressive alienation amongst young people enhance number of drug addicts, crimes committed by adolescents, depression cases or eating disorders [13]. There is also a correlation between the low EI and preferring Internet 
communication [14].

People, who have a lower sense of controlling themselves and others, easier fall into conflicts at work, faster become stressed, suffer from depression and even resign from work. Unemployment, in turn, is a one of the risk factors of depression $[13,15,16]$. EI is protecting against professional burnout [17, 18]. Intrapersonal intelligence, coping with stress and adaptability have a significant meaning in an average educational scores amongst pupils [19-21].

Scholars claim that these defensive mechanisms depend on social support and benefit from it. The mere fact of anchoring from environment does not mean that individual can appreciate it and use it to defend effectively nor cure depression $[9,11]$.

The authors have created a figure (fig.1) presenting relationships between several components of EI. High level of emotional intelligence lets generate deep and satisfactory interpersonal relationships, which are a support in difficult life situations. The emotional selfawareness allows to express emotions, what strengthens relationships, because it fosters a sense of trust and intimacy. Likewise, an accurate understanding of others' emotions is associated with higher empathy, which can result an emotional synchrony and interdependency. Both partners feel vulnerable to the negative effects of one's emotions and thus, they more readily monitor each other's feelings and offer support in early stages of crisis due to prevent from falling into deeper degradation, whereby they can suffer largely. Creating quantitatively large and qualitatively deep relationships provide more emotional support and tangible assistance during stressful, everyday challenges. This type of support helps people better appraise negative events and increase their self-esteem. The tangible support like lending money or doing a favour is associated with practical problem solving, what decreases a level of stress, protecting thereby against depression. The emotional self-awareness is closely connected with higher self-regard and selfactualization, which along with assertiveness, strengthen a social responsiveness for one's actions and words. All these qualities together cause more aware and accurate expressing one's emotions and feelings, what allow to create deep and satisfactory interpersonal relationships, drawing a sense of happiness, optimism and general mental well-being. The emotional self-awareness has also a great impact on reality testing, a rational situation assessment, which is essential for independent and flexible problem solving. An ability to control impulses is also favourable to effectively solve problems. Thereby, all components of emotional intelligence directly or indirectly protect against depression, so their low level can stand as a predictive factor of depression, which detected early enough lets prevent illness (fig.1) [6, 9, 11].

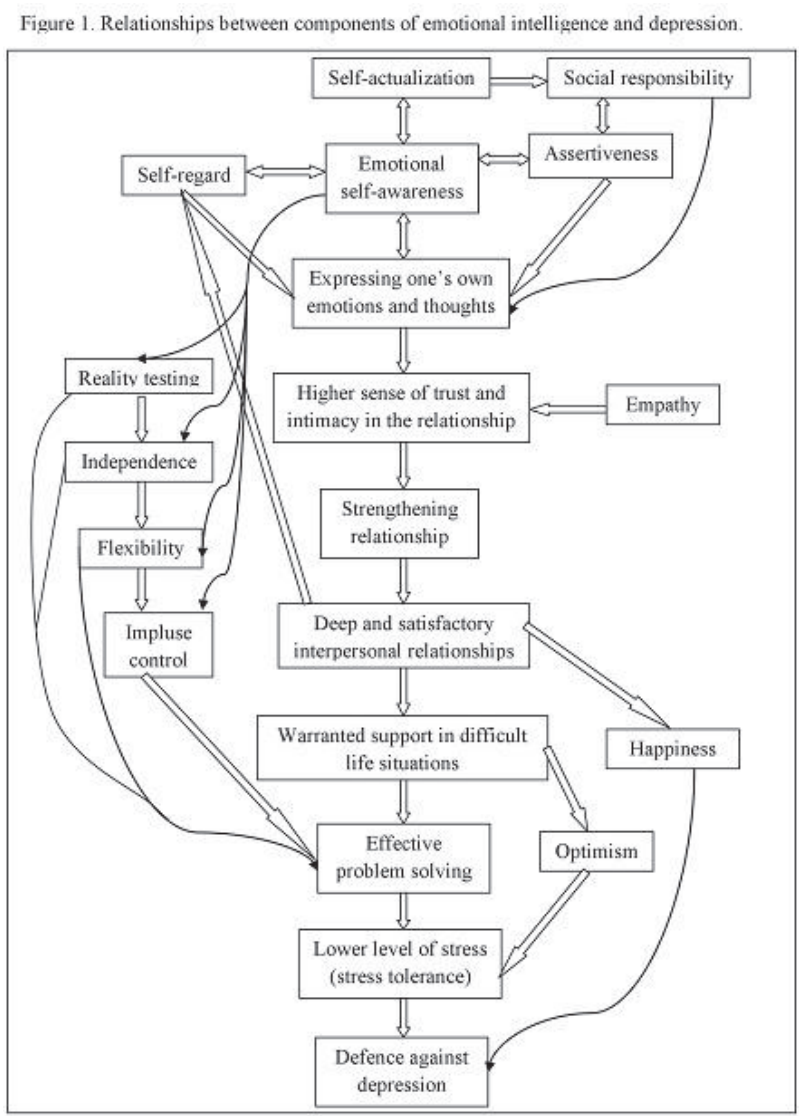

\section{Conclusions and recommendations.}

There is no doubt that the issue raised in this paper requires further, reliable investigations. It is necessary to develop verifiable, validated tests to measure levels of emotional intelligence and allow to effectively examine this feature. If reports from this publication confirm, it can open an ability to detect early predispositions to depression and therefore give basis to seek ways, in which we can improve emotional intelligence and as a result early prevent from this common illness. Perhaps, it would cause that an examination of EI level would be in the future an integral part of diagnosis and treatment of depression [4]. This kind of finding could cause a need to include this topic at schools or at least create broad programs informing about controlling one's emotional intelligence level, reacting earlier and helping protect people against depression [3]. 


\section{Wstęp}

Depresja jest jedną $\mathrm{z}$ najczęstszych chorób psychicznych, z którą styka się większość ludzi w trakcie swojego życia, zarówno bezpośrednio jak i pośrednio, poprzez znajomych bądź członków rodziny. Ponadto, depresja często prowadzi do myśli i prób samobójczych. Stąd, konieczna jest eksploracja tego zagadnienia i odnalezienie sposobów wczesnego wykrywania i profilaktyki depresji. W tym celu przez ostatnie dekady prowadzi się badania skupione na prawdopodobnej możliwości wykorzystania inteligencji emocjonalnej jako potencjalnego czynnika predykcyjnego depresji.

\section{Cel pracy}

Niniejsza praca jest przeglądem dostępnej literatury na temat wpływu poziomu inteligencji emocjonalnej na zapadalność na depresję. Ponadto, tekst ma za zadanie zwrócić uwagę środowiska naukowego na takie zastosowanie tego konstruktu i być może przyczynić się do dalszych badań na tym polu.

\section{Materiały i metoda}

W celu przeprowadzenia analizy na ten temat wykorzystano dostępne artykuły $\mathrm{z}$ bazy danych PubMed oraz Google Scholar pod hasłami: inteligencja emocjonalna, depresja, inteligencja emocjonalna a depresja w przedziale czasowym od 1999 do 2019 roku.

Dla jak najlepszego ukazania charakterystyki tego zagadnienia, artykuł podzielono na następujące podrozdziały:

1. Inteligencja emocjonalna - definicja i jej składowe.

2. Zależności między inteligencją emocjonalną a depresją.

3. Wyniki i dyskusja - poziom inteligencji emocjonalnej jako czynnik protekcyjny i predykcyjny depresji.

4. Podsumowanie - zalecenia.

\section{Inteligencja emocjonalna - definicja i jej składowe.}

Inteligencja emocjonalna (IE) (ang. Emotional Intelligence, EI) jest definiowana jako zdolność do postrzegania, rozumienia, zarządzania i różnicowania emocji zarówno własnych jak i innych osób [1]. Umożliwia ona rozpoznawanie stanów emocjonalnych i kierowanie nimi w taki sposób, aby regulować i dopasowywać zachowanie własne i innych do danej sytuacji, osiągać wyznaczone cele, radzić sobie w codziennych sytuacjach oraz forsować pozytywne doznania emocjonalne [2]. Dzięki IE ludzie lepiej przezwyciężają sytuacje stresowe, łatwiej rozwiązują konfliktowe sytuacje oraz mają bardziej pozytywne podejście do życia [3]. Jednym słowem, inteligencja emocjonalna umożliwia zdrowe funkcjonowanie mentalne, a poprzez to utrzymanie dobrostanu psychicznego [4].

Wielu badaczy twierdzi, iż konstrukt ten koreluje pozytywnie z psychospołecznymi czynnikami, takimi jak: poczucie dobrostanu, szczęścia, optymizmu, satysfakcji z życia, poczucia własnej godności, prospołecznych zachowań, zwiększonej jakości i ilości relacji społecznych oraz szczęścia w małżeństwie. Ponadto, inteligencja emocjonalna chroni przed objawami depresji, samotnością, antyspołecznymi zachowaniami, niepokojami społecznymi, tendencjami samobójczymi oraz uzależnieniem od alkoholu i innych substancji [3].

To Mayer i Salovey połączyli emocje oraz inteligencję, jako zdolności poznawcze, pod jednym pojęciem inteligencji emocjonalnej [5]. Bar-On, z kolei, stworzył szczegółowy i przejrzysty sposób podziału inteligencji emocjonalnej i dlatego na podstawie jego klasyfikacji będzie prowadzony dalszy przegląd tematu pracy. Według Bar-On’a inteligencja emocjonalna zbudowana jest z 5 głównych składowych, na które składa się 15 podkomponent: samoświadomość emocjonalna, asertywność, samoocena, samorealizacja, niezależność, empatia, odpowiedzialność społeczna, relacje międzyludzkie, poczucie rzeczywistości, elastyczność, umiejętność rozwiązywania problemów, tolerancja stresu, kontrola impulsów, optymizm i poczucie szczęścia $[2,3,6]$. Dokładny opis tab.1.

\section{Zależności między inteligencją emocjonalną a depresją.}

Pomimo nieznajomości pewnej przyczyny depresji, podejrzewa się, że czynniki psychologiczne, socjologiczne oraz fizjologiczne odgrywają tutaj istotną rolę [3]. Istnieje wiele hipotez łączących depresję m.in. z niezdolnością do kontrolowania negatywnych emocji [4] czy niskimi możliwościami dostosowania psychicznego [5]. Przeciwdziałać temu może odpowiedni poziom inteligencji emocjonalnej. Zdolności emocjonalne pozwalają radzić sobie i przezwyciężać depresję, poczucie beznadziejności oraz myśli samobójcze. Chronią jednostkę przed stresem i pozwalają łatwiej przystosowywać się do zmiennych warunków środowiska zewnętrznego [11].

Przeprowadzone badania na temat wpływu poziomu inteligencji emocjonalnej a tendencją do zapadalności na depresję wskazują, iż istnieje wyraźna relacja między tymi dwoma czynnikami $[2,3$, 4, 5, 7, 8, 9, 10]. Osoby, które uzyskują wyższe wyniki w testach na inteligencję emocjonalną zgłaszają również mniejsze nasilenie depresji [10]. Odkrycia te sugerują potencjalny wpływ IE na kliniczną depresję [4, 5].

Inteligencja emocjonalna jako część ogólnej inteligencji ludzkiej jest zdolnością do racjonalnego 
Tabela 1. Model inteligencji emocjonalnej według Bar-On’a [2,3,6].

\begin{tabular}{|c|c|c|}
\hline Ogólna komponenta & Nazwa podkomponenty & Charakterystyka \\
\hline \multirow{5}{*}{$\begin{array}{l}\text { Inteligencja Emocjonalna } \\
\text { Wewnątrzosobowa }\end{array}$} & Samoświadomość emocjonalna & Rozumienie i zarządzanie swoimi pragnieniami i emocjami \\
\hline & Asertywność & $\begin{array}{l}\text { Utrzymywanie swoich emocji, wierzeń, myśli i bronienie } \\
\text { własnych reguł }\end{array}$ \\
\hline & Samoocena & $\begin{array}{l}\text { Rozumienie siebie oraz akceptowanie i respektowanie tego } \\
\text { kim sięjest }\end{array}$ \\
\hline & Samorealizacja & Znajomość własnych zalet i wad oraz akceptowanie ich \\
\hline & Niezależność & $\begin{array}{l}\text { Kierowanie własnymi działaniami, myślami i ocenianie ich } \\
\text { wartości }\end{array}$ \\
\hline \multirow{3}{*}{$\begin{array}{l}\text { Inteligencja Emocjonalna } \\
\text { Międzyludzka }\end{array}$} & Empatia & Rozumienie emocji innych osób i respektowanie ich \\
\hline & Odpowiedzialność społeczna & $\begin{array}{l}\text { Wyrażanie siebie w grupie w aktywny i konstruktywny } \\
\text { sposób }\end{array}$ \\
\hline & Relacje międzyludzkie & $\begin{array}{l}\text { Posiadanie i podtrzymywanie satysfakcjonujących relacji } \\
\text { z innymi osobami poprzez okazywanie uprzejmości i } \\
\text { umiejętność jej przyjmowania }\end{array}$ \\
\hline \multirow{3}{*}{ Zdolność adaptacji } & Poczucie rzeczywistości & Oddzielanie wrażeń subiektywnych od obiektywnych \\
\hline & Elastyczność & $\begin{array}{l}\text { Dostosowywanie emocji, myśli i działań do zmieniających się } \\
\text { warunków otoczenia }\end{array}$ \\
\hline & $\begin{array}{l}\text { Umiejętność rozwiq̨zywania } \\
\text { problemów }\end{array}$ & $\begin{array}{l}\text { Zidentyfikowanie i zdefiniowanie problemu, a następnie } \\
\text { znalezienie potencjalnie odpowiedniego rozwiąania }\end{array}$ \\
\hline \multirow[t]{2}{*}{ Radzenie Sobie ze Stresem } & Tolerancja stresu & $\begin{array}{l}\text { Efektywne przeciwstawianie się stresujacym sytuacjom } \\
\text { i emocjom poprzez aktywne sposoby radzenia sobie ze } \\
\text { stresem }\end{array}$ \\
\hline & Kontrola impulsów & Kontrolowanie nagłych, silnych emocji \\
\hline \multirow{2}{*}{ Ogólne Samopoczucie } & Optymizm & $\begin{array}{l}\text { Utrzymywanie pozytywnego nastawienia nawet w obliczu } \\
\text { przeciwności losu }\end{array}$ \\
\hline & Poczucie szczęścia & Pozytywne nastawienie do życia, siebie i innych osób \\
\hline
\end{tabular}

myślenia, radzenia sobie $\mathrm{w}$ społeczeństwie oraz w zmiennym środowisku zewnętrznym. To pozwala rozwinąć bardzo dobre relacje międzyludzkie i posiadać lepsze wsparcie społeczne, kluczowe dla zapobiegania depresji [10].

Stopień w jaki człowiek potrafi kierować swoimi emocjami ma korzenie $w$ rozwoju emocjonalnym, doświadczeniach w ciągu życia związanych z emocjami, nastawieniu rodziców, ich sposobu traktowania i stymulowania dziecka do rozwoju emocjonalnego od wczesnego dzieciństwa aż do wieku dorosłego. Atmosfera i tło emocjonalne wyniesione $\mathrm{z}$ domu rodzinnego stanowią czynniki wpływające na poziom inteligencji emocjonalnej $[9,11,12]$.

Znaczenie ma rozmiar sieci towarzyskich, ich zróżnicowanie, częstotliwość kontaktów oraz poziom intymności pomiędzy ich członkami. Duże i zróżnicowane sieci towarzyskie pozwalają na większy wybór osób, do których można zwrócić się z danym problemem, aby uzyskać adekwatną pomoc. Poza tym, osoba może pełnić dzięki temu wiele ról społecznych, czuć się przez to bardziej istotną częścią swojego otoczenia, zwiększa jej samoocenę i sens życia. Co więcej, kontakt z różnorodnymi grupami i ludźmi wystawia jednostkę na różne sposoby radzenia sobie, co daje znajomość większej liczby mechanizmów rozwiązywania problemów.

Stresujące wydarzenia życiowe są jednym z najsilniejszych predyktorów depresji. Wysoki poziom inteligencji emocjonalnej, a co za tym idzie sprawne radzenie sobie $\mathrm{z}$ problemami, dzięki obecnym zasobom wewnętrznym i zewnętrznym jednostki, pozwalają na szybkie i efektywne rozwiązywanie kryzysów, a tym samym wskazują na protekcyjną rolę przeciwko depresji [6].

\section{Wyniki i dyskusja - poziom inteligencji emocjonalnej jako czynnik protekcyjny i predykcyjny depresji.}

W świetle przedstawionych dowodów można wyciągnąć wniosek, iż wysoki poziom inteligencji emocjonalnej działa jako czynnik protekcyjny depresji $[4,7,9]$. Z kolei niski poziom IE może stać się czynnikiem predykcyjnym depresji $[4,10]$. Komponenty inteligencji emocjonalnej chronią ludzi przed psychologicznymi napięciami [3]. 
Achenbach twierdzi iż, spadek poziomu inteligencji emocjonalnej jest zjawiskiem ogólnoświatowym. Ponadto, im wyższy iloraz inteligencji (IQ), tym niższe EI. Przykładami mogą tu być: coraz większa alienacja młodych ludzi, wzrastająca liczba narkomanów, przestępstw popełnianych przez młodocianych, przypadków depresji lub zaburzeń odżywiania [13]. Istnieje także korelacja między niskim EI, a preferowaniem komunikacji przez Internet [14].

Osoby, które mają mniejsze poczucie panowania nad sobą i otoczeniem łatwiej popadają w konflikty w pracy, szybciej się stresują, popadają $\mathrm{w}$ depresję, a nawet rezygnują z pracy. Z kolei, bezrobotność również jest jednym z czynników ryzyka depresji $[13,15,16]$. EI chroni także przed wypaleniem zawodowym $[17,18]$. Inteligencja wewnątrzosobowa, radzenie sobie ze stresem oraz zdolności do adaptacji mają istotne znaczenie w średnich wynikach w nauce wśród uczniów [19, 20.21].

Uczeni twierdzą, że mechanizmy protekcyjne IE zależą od wsparcia społecznego i umiejętności korzystania z niego. Sam fakt dawania oparcia przez otoczenie nie oznacza, że osoba będzie potrafiła to docenić i z niego skorzystać, a w wyniku tego chronić się skutecznie lub leczyć z depresji $[9,11]$.

Autorzy stworzyli rycinę (ryc.1) przedstawiającą relacje występujące pomiędzy poszczególnymi komponentami IE. Dzięki wysokiemu poziomowi inteligencji emocjonalnej jednostka potrafi wytworzyć głębokie i satysfakcjonujące relacje międzyludzkie, stanowiące wsparcie w trudnych sytuacjach życiowych. Samoświadomość własnych emocji pozwala na ich wyrażanie, co wzmacnia relacje z odbiorcą, ponieważ sprzyja to większemu poczuciu zaufania i intymności. Podobnie, dokładne rozumienie emocji innych osób, wzmaga empatię, co skutkuje poczuciem emocjonalnej synchronizacji i współzależności. Na obydwu partnerów relacji wpływają negatywne skutki ich emocji, dlatego chętniej monitorują oni wzajemne przeżycia i oferują wsparcie już we wczesnych etapach kryzysu, aby zapobiec popadnięciu w większą degradację na czym mogą bardziej ucierpieć. Utworzenie ilościowo wielu i jakościowo głębokich relacji zapewnia większe wsparcie emocjonalne i namacalną pomoc podczas stresujących wyzwań dnia codziennego. Takie wsparcie pomaga łatwiej oceniać negatywne zdarzenia i zwiększać samoocenę. Namacalna pomoc w postaci pożyczki pieniędzy lub wyświadczenia przysługi, wiąże się $\mathrm{z}$ praktyczną umiejętnością rozwiązywania problemów, co zmniejsza poziom stresu, chroniąc tym samym przed depresją. Samoświadomość emocjonalna wiąże się ściśle $\mathrm{z}$ wyższą samooceną i samorealizacją, które wraz z asertywnością wzmacniają poczucie odpowiedzialności społecznej za swoje czyny i słowa. Te wszystkie cechy razem powodują bardziej świadome i precyzyjne wyrażanie własnych emocji i myśli, co pozwala na tworzenie głębokich i satysfakcjonujących związków międzyludzkich, wywołujących poczucie szczęścia, optymizmu i ogólnego dobrostanu psychicznego. Samoświadomość emocjonalna ma również ogromny wpływ na poczucie rzeczywistości, racjonalną ocenę sytuacji, która jest niezbędna do niezależnego oraz elastycznego rozwiązywania problemów, czemu sprzyja także umiejętność kontrolowania impulsów. Tym samym wszystkie komponenty inteligencji emocjonalnej w sposób bezpośredni lub pośredni chronią przed depresją, a więc ich niski poziom może stanowić również czynnik predykcyjny depresji, który wykryty odpowiednio wcześnie pozwoli na zapobieżenie chorobie (ryc.1) [6, 9,

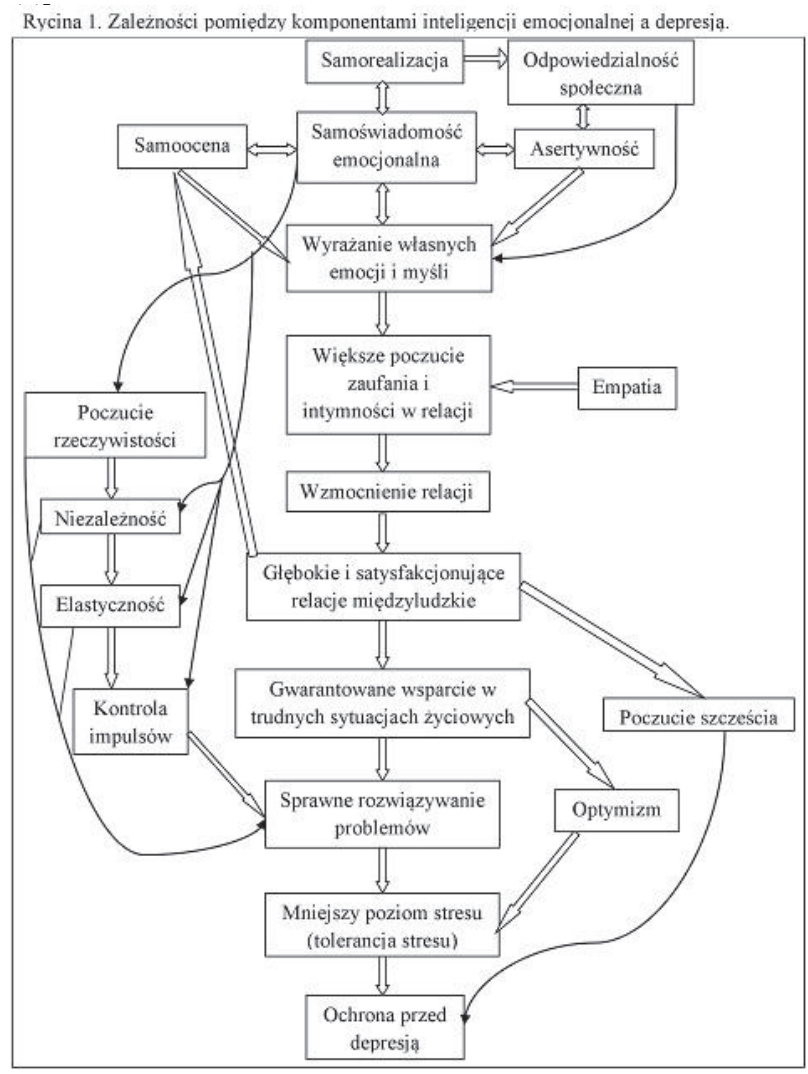

\section{Podsumowanie - zalecenia.}

Nie ulega wątpliwości, że tematyka poruszona w tej pracy wymaga dalszych, rzetelnych badań. Należy opracować wiarygodne, zwalidowane testy do pomiaru poziomu inteligencji emocjonalnej, które pozwolą efektywnie badać tą cechę. Jeśli zostaną potwierdzone doniesienia poruszone $\mathrm{w}$ tej publikacji, otworzy to możliwość wczesnego wykrywania predyspozycji do depresji, a co za tym idzie, da podstawy do szukania sposobów na rozwijanie inteligencji emocjonalnej i w efekcie wczesne zapobieganie tej wszechobecnej chorobie. Być może spowoduje to również, że badanie poziomu IE będzie w przyszłości integralną częścią procesu diagnostycznego i leczenia depresji [4]. Takie odkrycie mogłoby spowodować także potrzebę 
włączenia tego tematu do powszechnej nauki w szkole lub przynajmniej stworzenia szerokich programów informujących o kontrolowaniu i podnoszeniu swojego poziomu IE, co pozwoliłoby wcześniej reagować i chronić przed pojawieniem się depresji [3].

\section{Conflict of interest}

The authors have declared no conflict of interest.

\section{References:}

1. Shabany M., Ghajarzadeh M. Emotional Intelligence and Depression Among Hospital Nurses of Tehran University of Medical Sciences. Arch Neurosci., October 2018; 5(4): e70734.

2. Motahari A.A., Rahgozar S. Inhibitory Role of Emotional Intelligence in Committing Suicide. Indian J. Sci. Technol., November 2011; 4(11): 1601-1606.

3. Rahgozar S., Motahari A.A., Zolali A. Assessing Bar-On's Emotional Intelligence Components Among Normal Subjects and Those of Having Suicide Trial Record. Indian J.Sci.Technol., October 2011; 4(10): 1391-1395.

4. Downey LA, Johnston PJ, Hansen K, Schembri R, Stough C, Tuckwell V, et al. The Relationship Between Emotional Intelligence and Depression in a Clinical Sample. Eur.J.Psychiat. 2008; 22(2): 93-98.

5. Al.-Tarawneh A.A., Nizami N. Relationship Between Emotional Intelligence and Adolescents' Depression. Inter.J.R., April 2016; 3(8): 39-44.

6. Bar-On R. The Bar-On Model of Emotional-Social Intelligence. Psicothema, February 2006; 17.

7. Rode J. The Protective Effects of Social Support on Postpartum Depression: Does Emotional Intelligence Matter?, Cincinnati; M.S. Indiana University-Purdue University-Indianapolis: March 2013.

8. Du Plooy H. The Relationship Between Emotional Intelligence and Suicide Behaviour Among South African Adolescents, Bloemfontein; University of The Free State: January 2017, s. $50-90$.

9. Sapra M. A Study of Stress, Anxiety and Depression in Secondary School Students in Relation to Their Emotional Intelligence. Inter.J.Ad.Res.Develop., January 2018; 3(1): 361-366.

10. Parihar N., Jha M. Role of Emotional Intelligence, Gender and Culture in Depression. J.Hum.S.Sci., February 2015; 20(2): 3336.
11. Du Plooy H. The Moderating Role of Emotional Intelligence in The Relationship Between Psychosocial Factors and Suicide Behaviour in South African Adolescents, Bloemfontein; University of The Free State: January 2017, s. 91-154.

12. Martowska K. Inteligencja Emocjonalna Licealistów a Oddziaływania Wychowawcze Rodziców. Ruch Pedag., 2009; 3(4): 55-69.

13. Goleman D. Inteligencja emocjonalna w praktyce. Poznań: Media Rodzina; 1999.

14. Henne K. Kompetencja Społeczna i Inteligencja Emocjonalna a Zaangażowanie w Internet. Psychologia Jakości Życia, 2003; 2(1): 111-130.

15. Caban J.M., Rewerski T. Inteligencja Emocjonalna i Kompetencje Społeczne u Osób Pracujących i Bezrobotnych. Polityka Społ., 2005; 2: 8-10.

16. Stańczyk J., Gajdziszewska-Dudek P. O Znaczeniu Inteligencji Emocjonalnej w Życiu Zawodowym. Zeszyty Nauk.Politech. Śląskiej, 2015; 85: 507-516.

17. Wróbel M. Emotional Labor and Burnout in Teachers: The Moderating Role of Emotional Intelligence. Psych.Społ., 2013; 24(1): 53-66

18. Ogińska-Bulik N. Stres Zawodowy i Jego Konsekwencje w Grupie Pracowników Sektora Usług Społecznych - Rola Inteligencji Emocjonalnej. Przeg.Psych., 2008; 51(1): 69-85.

19. Sadowska M., Brachowicz M. Struktura Inteligencji Emocjonalnej. KUL, 2008; 15: 65-79.

20. Szczygieł D. Inteligencja Emocjonalna i Powodzenie Szkolne. Psych.Roz., 2005; 10(1): 59-68.

21. Karwowski M. Inteligencja "Akademicka", Emocjonalna i Zdolności Twórcze Uczniów o Różnych Osiągnięciach Szkolnych. Stud. Psych., 2004; 5: 103-115.

\section{Corresponding author}

\author{
Ewelina Soroka \\ II Department of Psychiatry and Psychiatric \\ Rehabilitation, Medical University of Lublin \\ e-mail: dziwota.e@gmail.com
}

Otrzymano: 07.05.2019

Zrecenzowano: 29.05.2019, 27.08.2019

Przyjęto do druku: 18.10.2019 